\title{
ETHNOBOTANY STUDY OF VEGETABLE SPECIES WITH THERAPEUTIC PURPOSES FROM A RURAL COMMUNITY IN THE MUNICIPALITY OF BARBALHA, CEARÁ, BRAZIL
}

\author{
ESTUDO ETNOBOTÂNICO DE ESPÉCIES VEGETAIS COM FINS \\ TERAPÊUTICOS EM UMA COMUNIDADE RURAL NO MUNICÍPIO DE \\ BARBALHA, CEARÁ, BRASIL
}

Sara Tavares de Sousa Machado*1, Jéssica Pereira de Sousa ${ }^{2}$, Paulo Ricardo Batista ${ }^{1}$, Denise Bezerra Correia ${ }^{1}$, Cícero Damon Carvalho de Alencar ${ }^{1}$, Joice Barbosa do Nascimento ${ }^{1}$, Cícera Norma Fernandes Lima ${ }^{2}$

Cariri Regional University - URCA, Coronel Antônio Luis, 1161 - 63105-000 - Crato, Ceará, Brazil; e-mail: saratavares17@hotmail.com

${ }^{2}$ Federal Rural University of Pernambuco (UFRPE), Manuel de Medeiros, s/n - Dois Irmãos, 52171-900, Recife, Pernambuco, Brazil.

\begin{abstract}
From the beginnings of mankind man recurs to natural resources for the treatment, cure and prevention of various diseases through the use of medicinal plants. The objective of this study was to revitalize and identify the knowledge regarding plant species with therapeutic purposes used by the traditional Santo Antônio community, Barbalha, Ceará, Brazil, with the aim of assisting chemical and pharmacological studies. The methodology was based on semi-structured interviews to explore informant's knowledge surrounding medicinal species and to highlight those considered more versatile. 27 species were described, distributed across 21 distinct families, of which the most representative was the Anacardiaceae family. From these species, 05 have gained prominence regarding their versatility: Chenopodium ambrosioides L., Helianthus annuus L., Bauhinia variegata L., Anethum graveolens L., Passiflora cincinnata Mast. In general, the leaf was the most used plant part. As for preparation method, infusion prevailed. For therapeutic purpose, a greater use in disease cases involving problems such as scarring, hypertension, anxiety and diabetes was observed. Most of the indications reported by the local community coincide with findings in the literature, thus, this research may serve as a subsidy for pharmacological and chemical studies which may lead to the discovery of new herbal medicines.
\end{abstract}

Keywords: ethnobiology, medicinal plants, pharmacological study, traditional community, therapeutic indications.

Resumo: Desde o início da humanidade, o homem recorre aos recursos naturais para o tratamento, cura e prevenção de várias doenças através do uso de plantas medicinais. O objetivo deste estudo foi revitalizar e identificar o conhecimento sobre espécies vegetais com fins terapêuticos utilizados pela comunidade tradicional de Santo Antônio, Barbalha, Ceará, Brasil, com o objetivo de auxiliar estudos químicos e farmacológicos. A metodologia foi baseada em entrevistas semiestruturadas para explorar o conhecimento dos informantes em torno das espécies medicinais e destacar aquelas consideradas mais versáteis. Foram descritas 27 espécies, distribuídas em 21 famílias distintas, das quais a mais representativa foi a família Anacardiaceae. Destas espécies, 05 ganharam destaque em termos de versatilidade: Chenopodium ambrosioides L., Helianthus annuus L., Bauhinia variegata L., Anethum graveolens L., Passiflora cincinnata Mast. Em geral, a folha foi a parte da planta mais utilizada. Quanto ao método de preparação, a infusão prevaleceu. Para fins terapêuticos, observou-se maior uso em casos de doenças que envolvem problemas como cicatrizes, hipertensão, ansiedade e diabetes. A maioria das indicações relatadas pela comunidade local coincide com os achados da literatura, portanto, esta pesquisa pode servir como subsídio para estudos farmacológicos e químicos que podem levar à descoberta de novos fitoterápicos.

Palavras-chave: etnobiologia, plantas medicinais, estudo farmacológico, comunidade tradicional, indicações terapêuticas. 


\section{INTRODUCTION}

Since antiquity, humanity has sought alternatives to deal with physical and psychic illnesses. Such care differs according to the communities' social culture over the years. Thus, cultural concepts are of utmost relevance in the construction of knowledge that involves the health-disease process (SIQUEIRA, 2006).

In Brazil, it is evident that the knowledge and medicinal use of plant species especially by quilombola, riverine, rural, traditional and indigenous communities remains an important therapeutic resource in the management of diseases, especially because it is easily accessible and inexpensive (VÁSQUEZ; SANTANA; NODA, 2014).

It is believed that care taken through medicinal plants is favorable to human health provided the user has prior knowledge of its purpose, risks and benefits. From the scientific point of view, studies prove the benefits obtained through the medicinal use of plant species, however, despite their natural origin some plants have harmful substances and many are unaware of the real effects of these substances in the organism (FRANÇA, 2008).

Thus, attention from health authorities and administrations directed at the medicinal use of plants has considerably increased in recent years, since most of the plant species usually used in selfmedication do not have a well-known toxic profile and pose health risk (SOUZA-MOREIRA; SALGADO; PIETRO, 2010).

Therefore, these prophylactic and therapeutic home measures are performed with the intention of seeking or maintaining a state of well-being close to what is said to be ideal. These practices are usually performed within the family environment and almost always passed over generations (SIQUEIRA, 2006).

Based on these considerations, this study aimed to identify native and exotic plant species with therapeutic purpose which are used by a traditional community of the Chapada do Araripe in the state of Ceará. This community has knowledge regarding the use of these specimens for prophylaxis and treatments, with respect to the diseases they affect. Moreover, because this community is located in the Cerrado biome, which has a complex vegetation profile with great biological diversity, occupying a large territorial area in Brazil and with a greater population concentration, the importance of this study is justified.

\section{MATERIALS AND METHODS Study location}

The study was carried out in the Santo Antônio community, located in the Arajara district, in the municipality of Barbalha, Ceará, Brazil, a traditional community which still has a significant rural population using plants for medicinal purposes.

The city of Barbalha has a population of 55,323 inhabitants and is located 553 kilometers from the state capital (Fortaleza), in the Metropolitan Region of Cariri, Meso-region of Southern Ceará. The aforementioned municipality is located at the foot of the Chapada do Araripe, located between the geographical coordinates: Latitude: $7^{\circ} 18^{\prime} 40^{\prime \prime}$ South and Longitude: $39^{\circ} 18^{\prime} 15^{\prime \prime}$ West. Together with the cities of Crato and Juazeiro do Norte, Barbalha makes up the Crajubar triangle in the Cariri valley region with the the FLONA (Araripe National Forest) surrounding them (IBGE, 2010).

This municipality's climate is a hot-mild tropical semi-arid with a predominantly caatinga vegetation, however, it also presents cerradão and cerrado domains. A rainy period between January and April, with average rainfall of $1,153.0$ millimeters per year is observed with an average daily maximum temperature between 24 and $26^{\circ} \mathrm{C}$ for most of the year (IPECE, 2016).

\section{Tools and procedures for data collection}

Data collection was performed between July and October 2017 using semi-structured interviews based on standardized forms (MARTIN, 1995), where information about the interviewees's knowledge was obtained after the reading, permission and signing of the informed consent form (PIC, Prior Informed Consent), moreover, International Society of Ethnobiology's ethical guidelines (2006) were adopted.

Initially, a closed questionnaire was used to obtain the socio-economic characteristics of the research subjects (age, sex, occupation, residence time in the locality), followed by the botanical data (popular name of the plant, part used, form of preparation and therapeutic indications, access availability) which were obtained through a semi-structured interview script. 
Eighteen individuals were interviewed, including men and women between the ages of 22 and 92 years. The key informants of this study were selected using the non-probabilistic "snowball" sampling method, these indicated others with the potential to contribute to the study, until the socalled "saturation point" was reached, that is, when the indicated names started to be repeated (ALBUQUERQUE; LUCENA; CUNHA, 2010).

\section{Data analysis}

For the species versatility, the relative importance (RI) index of each medicinal species cited by the informants were calculated, as proposed by Bennett and Prance (2000) using the formula: RI = NSC+NP, where NSC: corresponds to the number of body systems treated by the species (NSCE), divided by the number of body systems treated by the most versatile species (NSCEV); and NP: corresponds to the number of properties attributed to a particular species (NPE), divided by the total number of properties attributed to the most versatile species (NPEV), with 2.00 being the maximum value obtained by a species.

\section{RESULTS}

\section{Sociodemographic profile}

A total sample of the research consisted of 18 participants, 55.56\% of whom were female and $44.44 \%$ male. Most of the interviewees were concentrated in the age group of 28 to 37 years (33.34\%) and the most reported marital status was married (66.67\%). Considering the level of education, 5 (27.78\%) interviewees reported not having completed elementary school, there was also the declaration of non-schooled people, a reality mentioned by $5.55 \%$ participants. The prevalent profession is that of a farmer, representing $66.67 \%$ of the sample. Regarding the time of residence in the area, $44.44 \%$ participants reported living in the area for a period $\geq 30$ years.

\section{Ethnobotanical knowledge}

A total of 27 botanical species were mentioned in the treatment and prevention of diseases, where the most cited are distributed in 21 distinct families, with the family Anacardiaceae with 3 spp., and the Poaceae, Passifloraceae, Rutaceae, Asteraceae families each with 2spp. standing out. The species with the highest relevance indices were Chenopodium ambrosioides L. (2.0), Helianthus annuus L. (1.6), Bauhinia variegata L. (1.5), Anethum graveolens L. (1.5) and Passiflora cincinnata Mast. (1.5).

As for the most used parts, the leaves had the highest number of citations (38\%), followed by the fruits (21\%), bark (17\%), seeds (14\%), bast (7\%) and bulbs (3\%) (Figure 1). With the preparation method, a predominant use of infusion (32\%), followed by decoction (29\%), juice (13\%), sauce $(10 \%)$, oil (6.5\%), syrup (6.5\%) and bath (3\%) (Figure 2).

In the present study, 22 therapeutic indications were reported, with a total of 11 species being indicated for scarring, represented in Table 1. Next, nine species were cited for an antihypertensive activity, with problems such as anxiety and diabetes receiving five and four species indications, respectively. Plants used for the treatment of skin diseases corresponded to the highest citations by the interviewees.

Table 1. Relation of medicinal species indicated by the interviewees of the Santo Antônio Community, Ceará, Brazil.

\begin{tabular}{|c|c|c|c|c|c|c|}
\hline Scientific name /Family & Local names & Hábito & $\begin{array}{l}\text { Used } \\
\text { part }\end{array}$ & Preparation & Indications & IR \\
\hline $\begin{array}{l}\text { URTICACEAE } \\
\text { Cecropia glaziovii }\end{array}$ & Toré & Arboreal & $\begin{array}{l}\text { Aerial } \\
\text { parts }\end{array}$ & Decoction & Healing & 0,5 \\
\hline $\begin{array}{l}\text { ANACARDIACEAE } \\
\text { Myracrodruon urundeuva } \\
\text { Anacardium ooccidentale } \\
\text { Spondias lutea }\end{array}$ & $\begin{array}{l}\text { Aroeira } \\
\text { Caju } \\
\text { Cajarana }\end{array}$ & Arboreal & $\begin{array}{l}\text { Bark } \\
\text { Bast } \\
\text { Bast }\end{array}$ & $\begin{array}{l}\text { Decoction, } \\
\text { syrup, on the } \\
\text { water, infusion } \\
\text { On the water, } \\
\text { topic, fruits } \\
\text { Decoction }\end{array}$ & $\begin{array}{l}\text { Uterine } \\
\text { inflammation, } \\
\text { cough } \\
\text { Inflammation, } \\
\text { healing } \\
\text { Healing }\end{array}$ & $\begin{array}{l}1,3 \\
0,7\end{array}$ \\
\hline
\end{tabular}




\begin{tabular}{|c|c|c|c|c|c|c|}
\hline Scientific name /Family & Local names & Hábito & $\begin{array}{l}\text { Used } \\
\text { part }\end{array}$ & Preparation & Indications & IR \\
\hline $\begin{array}{l}\text { ASTERACEAE } \\
\text { Helianthus annuus } \\
\text { Matricaria chamomilla } \\
\end{array}$ & $\begin{array}{l}\text { girassol } \\
\text { camomila }\end{array}$ & Herbaceous & $\begin{array}{l}\text { Seeds } \\
\text { Aerial } \\
\text { parts }\end{array}$ & $\begin{array}{l}\text { Infusion } \\
\text { Decoction }\end{array}$ & $\begin{array}{l}\text { Labyrinthitis, } \\
\text { stroke, } \\
\text { hypertention } \\
\text { Hypertention, } \\
\text { anxiety, sleep } \\
\text { disturbance }\end{array}$ & $\begin{array}{l}1,6 \\
1,1\end{array}$ \\
\hline $\begin{array}{l}\text { FABACEAE } \\
\text { Bauhinia variegata }\end{array}$ & pata de vaca & Arboreal & $\begin{array}{l}\text { Bast, } \\
\text { Bark }\end{array}$ & Syrup, infusion & $\begin{array}{l}\text { Cough, flu, } \\
\text { phlegm in the } \\
\text { lung, healing }\end{array}$ & 1,5 \\
\hline $\begin{array}{l}\text { AMARANTHACEAE } \\
\text { Chenopodium ambrosioides }\end{array}$ & mastruz & Herbaceous & $\begin{array}{l}\text { Aerial } \\
\text { parts }\end{array}$ & $\begin{array}{l}\text { Infusion, on the } \\
\text { water }\end{array}$ & $\begin{array}{l}\text { Flu, } \\
\text { inflammation, } \\
\text { knock, } \\
\text { vermifuge, } \\
\text { healing } \\
\end{array}$ & 2 \\
\hline $\begin{array}{l}\text { LAMIACEAE } \\
\text { Melissa officinalis }\end{array}$ & cidreira & Herbaceous & $\begin{array}{l}\text { Aerial } \\
\text { parts }\end{array}$ & Infusion & $\begin{array}{l}\text { Hypertention, } \\
\text { anxiety }\end{array}$ & 1,1 \\
\hline $\begin{array}{l}\text { LILIACEAE } \\
\text { Allium sativum }\end{array}$ & alho & Herbaceous & Bulb & Infusion & $\begin{array}{l}\text { Cough, } \\
\text { hypertention }\end{array}$ & 1,1 \\
\hline $\begin{array}{l}\text { MYRISTICACEAE } \\
\text { Myristica fragrans }\end{array}$ & noz-moscada & Arboreal & Seeds & $\begin{array}{l}\text { Seed } \\
\text { consumption, } \\
\text { Infusion } \\
\end{array}$ & $\begin{array}{l}\text { Hypertention, } \\
\text { diabetes }\end{array}$ & 0.7 \\
\hline $\begin{array}{l}\text { MALVACEAE } \\
\text { Abelmoschus esculentus }\end{array}$ & quiabo & Shrubby & Fruits & Topic & Healing & 0,7 \\
\hline $\begin{array}{l}\text { RUTACEAE } \\
\text { Citrus limon } \\
\text { Citrus sinensis } \\
\end{array}$ & $\begin{array}{l}\text { limão } \\
\text { laranja }\end{array}$ & Arboreal & $\begin{array}{l}\text { Aerial } \\
\text { parts }\end{array}$ & $\begin{array}{l}\text { Decoction } \\
\text { Infusion }\end{array}$ & Anxiety, flu & 1,1 \\
\hline $\begin{array}{l}\text { CUCURBITACEAE } \\
\text { Sechium edule }\end{array}$ & chuchu & Herbaceous & Fruits & Juice & $\begin{array}{l}\text { Hypertention, } \\
\text { fever }\end{array}$ & 1,1 \\
\hline $\begin{array}{l}\text { APIACEAE } \\
\text { Anethum graveolens }\end{array}$ & endro & Herbaceous & Seeds & Infusion & $\begin{array}{l}\text { Flatulence, } \\
\text { gastrointestinal } \\
\text { spasms, anxiety }\end{array}$ & 1,5 \\
\hline $\begin{array}{l}\text { PASSIFLORACEAE } \\
\text { Passiflora cincinnata } \\
\text { Passiflora edulis }\end{array}$ & $\begin{array}{l}\text { Maracujá- } \\
\text { bravo } \\
\text { maracujá }\end{array}$ & Bindweed & Fruits & Juice & $\begin{array}{l}\text { Cancer, diabetes, } \\
\text { hypertention } \\
\text { Cough, } \\
\text { inflammation, } \\
\text { soothing } \\
\text { anxiety }\end{array}$ & $\begin{array}{l}1,5 \\
0,5\end{array}$ \\
\hline $\begin{array}{l}\text { ZINGIBERIACEAE } \\
\text { Alpinia zerumbet }\end{array}$ & colônia & Herbaceous & $\begin{array}{l}\text { Aerial } \\
\text { parts }\end{array}$ & Infusion & $\begin{array}{l}\text { Diabetes, } \\
\text { hypertention }\end{array}$ & 0,7 \\
\hline $\begin{array}{l}\text { SOLANACEAE } \\
\text { Solanum melongena } \\
\end{array}$ & beringela & Herbaceous & Fruits & Juice & $\begin{array}{l}\text { Diabetes, } \\
\text { hypertention }\end{array}$ & 0,7 \\
\hline $\begin{array}{l}\text { POACEAE } \\
\text { Cymbopogon citratus } \\
\text { Saccharum officinarum }\end{array}$ & $\begin{array}{l}\text { capim-santo } \\
\text { cana }\end{array}$ & $\begin{array}{l}\text { Herbaceous } \\
\text { Herbaceous }\end{array}$ & $\begin{array}{l}\text { Aerial } \\
\text { parts }\end{array}$ & $\begin{array}{l}\text { Infusion } \\
\text { Decoction }\end{array}$ & $\begin{array}{l}\text { Hoarseness, } \\
\text { soothing } \\
\text { Hypertention }\end{array}$ & $\begin{array}{l}1,1 \\
0,5 \\
\end{array}$ \\
\hline $\begin{array}{l}\text { NYCTAGINACEAE } \\
\text { Boerhavia diffusa }\end{array}$ & pega-pinto & Herbaceous & $\begin{array}{l}\text { Aerial } \\
\text { parts }\end{array}$ & Decoction, bath & Healing & 0,5 \\
\hline $\begin{array}{l}\text { MUSACEAE } \\
\text { Musa } \mathrm{sp} .\end{array}$ & bananeira & Herbaceous & Bark & Oil & Healing & 0,5 \\
\hline $\begin{array}{l}\text { APOCINACEAE } \\
\text { Himatanthus obovatus }\end{array}$ & janaguba & Arboreal & $\begin{array}{l}\text { Aerial } \\
\text { parts }\end{array}$ & Decoction & $\begin{array}{l}\text { Cancer, healing, } \\
\text { edema }\end{array}$ & 0,7 \\
\hline $\begin{array}{l}\text { MORACEAE } \\
\text { Morus celtidifolia }\end{array}$ & amora & Shrub & Fruits & Topic & $\begin{array}{l}\text { Healing, anxiety, } \\
\text { muscle aches }\end{array}$ & 0,7 \\
\hline $\begin{array}{l}\text { LAURACEAE } \\
\text { Persea americana }\end{array}$ & abacateiro & Arboreal & Bark & Oil & $\begin{array}{l}\text { Healing, sleep } \\
\text { disturbance }\end{array}$ & 0,7 \\
\hline
\end{tabular}




\section{DISCUSSION}

Sousa, Oliveira e Conceição (2014) recorded the Anacardiaceae, Lamiaceae and Poaceae families as those with greater quantitative representation, while the Asteraceae family obtained prominence in the study by Teixeira and Melo (2006). The Asteraceae family was the most representative, in terms of species number, corroborating with results presented by the majority of medicinal plant surveys conducted, such as those by Cajaiba et al (2016); Rodrigues and Andrade (2014).

In relation to the plant parts used, the leaves received a greater number of citations, due to its easy availability throughout the year (CASTELLUCCI et al., 2000). In addition, its use is also due to the easy cultivation. Another reason for this would be the fact that chemical mechanisms and active principles are concentrated in these parts of the plant (CHEEKE, 1998). These results concur with other ethnobotanical surveys (SILVA; MARINI; MELO, 2015, SANTANA; NETO, 2017).

The preparation method of medicinal plants for use in the treatment of diseases is a point of great importance since this often depends on the therapeutic action of the plant. In our study, infusion was the most used form of preparation with similar studies justifying the present research data (MONTELES; PINHEIRO, 2007; ALBERTASSE; THOMAZ; ANDRADE, 2010; BATTISTI et al., 2013).

From the species presented in this study, five showed the greatest versatility as well as great relative importance: Chenopodium ambrosioides L., Helianthus annuus L., Bauhinia variegata L., Anethum graveolens L., Passiflora cincinnata Mast.

Within the 71 plant species present in the Medicinal Plants National Relation of Interest to SUS - RENISUS (BRASIL, 2009), is Chenopodium ambrosioides L., popularly known in Brazil as mastruz (ALBUQUERQUE et al., 2009a). This is a widely used species studied across the national territory, in studies such as those by Costa and Marinho (2016); Franco and Sousa (2016). Pharmacological studies reveal their anti-helminthic properties (SÁ; SOARES; RANDAU, 2015; SILVA et al., 2016; FENALTI et al., 2016), analgesic and anti-inflammatory properties (TRIVELLATOGRASSI et al., 2013) in addition to its antimicrobial (BRAHIM et al., 2015) and antitumor potential (ABREU; SILVA; OLIVEIRA, 2017), results of which are in agreement with the uses cited by the interviewed population.

Despite frequent Helianthus annuus L. citation in ethnobotanical surveys for combating strokes (ARAÚJO et al., 2015), no studies were found in the literature to prove this effect. However, Emamuzo et al (2010) have shown that sunflower has analgesic and anti-inflammatory effects.

Bauhinia variegata L., commonly known as "pata de vaca" (cow's paw), has pharmacological properties reported in the literature such as antioxidant, cholesterol and triglyceride reducing activity (RAJANI and ASHOK 2009), as well as antimicrobial potential (SHARMA; KALAUNI; AWALE, 2015).

Anethum graveolens L. (dill), in studies by Oshaghi et al (2016), report their antioxidant activity, as well as their action in diabetes prevention. In addition, pharmacological tests performed by Singh et al (2017) revealed its antimicrobial activity.

Passion fruit (Passiflora cincinnata Mast.) has been indicated in the fight against insomnia, with the leaves and fruits being indicated for the treatment of hypertension, coughs, inflammations as well as a sedative and anxiolytic. Although widely indicated, with the species being cited in several ethnobotanical surveys, there are no studies reporting its pharmacological properties.

In addition to the contributions described above, two aspects of intriguing relevance were identified in the results obtained in this study:

a) Among the ranking of the five most versatile and important plant species for the community, three are exotic. Ribeiro et al. (2014) found a predominance of exotic species in their ethnobotanical survey also in southern Ceará, affirming that this situation is common and reporting possible causes, such as the need to expand the local pharmaceutical stock and the availability and easy cultivation of exotic species;

b) Therapeutic indications unpublished in the ethnopharmacobotanical literature, were reported by the informants. Thus, this research can help future ethnopharmacological studies focusing on these bioactivities in order to validate them scientifically.

\section{CONCLUSION}


In view of the data collected in this study, a significant knowledge within the interviewed population regarding practices involving plants for therapeutic purposes was observed. For the most part, plants are used both in prophylaxis and in the treatment of pathologies, with these uses being transmitted to subsequent generations.

The permanence of this practice by traditional communities is mainly due to difficult access to health centers and the high cost of synthetic medicines. In addition, cultural aspects directly collaborate in the construction of knowledge. Thus, this information is important to contribute to the valorization of traditional knowledge about medicinal plants, can be reversed in actions to promote local health and instigate ethnobotanical studies that strive to characterize the traditional knowledge of native and exotic local floras.

\section{REFERÊNCIAS}

ABREU, M. C.; SILVA, P. H.; OLIVEIRA, Y. R. Vegetais cultivados em quintais rurais Piauienses com indicação anticâncer: uma busca pelo conhecimento tradicional. Ciência e Natura, v. 39, n. 1, p. 22-32, 2017.

ALBERTASSE, P. D.; THOMAZ, L. D.; ANDRADE, M. A. Plantas medicinais e seus usos na comunidade da Barra do Jucu, Vila Velha, ES. Revista Brasileira de Plantas Medicinais, v. 12, n. 3, p. 250-260, 2010.

ALBUQUERQUE, U.P.; ARAÚJO, T.A.S.; RAMOS, M.A.; NASCIMENTO, V.T.; LUCENA, R.F.P.; MONTEIRO, J.M.; ARAÚJO, E.L. How ethnobotany can aid biodiversity conservation: reflections on investigations in the semi-arid region of NE Brazil. Biodiversity and Conservation, v. 18, n. 1, p. 127-150, 2009.

ALBUQUERQUE, U.P.; LUCENA, R.F.P.; CUNHA, L.V.F. Métodos e Técnicas na Pesquisa Etnobiológica e Etnoecológica. 1 ed. Recife: NUPEEA, 2010. p. 559.

ARAÚJO, I.; SOUZA, L.; GUARÇONI, E.A.E.; FIRMO, W.C.A. O comércio de plantas com propriedades medicinais na cidade de Bacabal, Maranhão, Brasil. Natureza Online, v. 13, p. 111-116, 2015.

BATTISTI, C.; GARLET, T.M.B.; ESSI, L.; HORBACH, R.K.; ANDRADE, A.; BADKE, M.R. Plantas medicinais utilizadas no município de Palmeira das Missões, RS, Brasil. Revista Brasileira de Biociências, v. 11, n. 3, p. 338-348, 2013.

BENNETT, B. C.; PRANCE, G. T. Introduced plants in the indigenous pharmacopoeia of Northern South America. Economic botany, v. 54, n. 1, p. 90-102, 2000.

BRAHIM.; M.A.S.; FADLI, M.; HASSANI, L.; BOULAY, B.; MARKOUK, M.; BEKKOUCHE, K.; LARHSINI, M. Chenopodium ambrosioides var. ambrosioides used in Moroccan traditional medicine can enhance the antimicrobial activity of conventional antibiotics. Industrial Crops and Products, v. 71, p. 37-43, 2015.

BRASIL. Ministério da Saúde. RENISUS - Relação Nacional de Plantas Medicinais de Interesse ao SUS. Espécies vegetais. DAF/SCTIE/MS - RENISUS - fev/2009. Disponível em: $\langle$ http://bvsms.saude.gov.br/bvs/sus/pdf/marco/ms_relacao_plantas_medicinais_sus_0603.pdf >. Acesso em janeiro de 2018.

CAJAIBA, R.L.; SILVA, W.B.; SOUSA, R.D.N.; SOUSA, A.S. Levantamento etnobotânico de plantas medicinais comercializadas no município de Uruará, Pará, Brasil. Biotemas, v. 29, n. 1, p. 115-131, 2016.

CASTELLUCCI, S.; LIMA, M.I.S.; NORDI, N.; MARQUES, J.G.W. Plantas medicinais relatadas pela comunidade residente na Estação Ecológica Jataí, Município de Luís Antônio/SP: uma abordagem ecológica. Revista Brasileira de Plantas Medicinais, v. 3, n. 1, p. 51-60, 2000.

CHEEKE, P. R. Natural toxicants in feeds, forages, and poisonous plants. Interstate Publishers, Inc., PO Box 50., 1998.

COSTA, J. C.; MARINHO, M. G. V. Etnobotânica de plantas medicinais em duas comunidades do município de Picuí, Paraíba, Brasil. Revista Brasileira de Plantas Medicinais, p. 125-134, 2016.

EMAMUZO, E.D.; MINIAKIRI, S.I.; TEDWIN, E.J;O.; UFOUMA, O.; LUCKY, M. Analgesic and anti-inflammatory activities of the ethanol extract of the leaves of Helianthus Annus in Wistar rats. Asian Pacific Journal of Tropical Medicine, v. 3, n. 5, p. 341-347, 2010. 
FENALTI, J.M.; SANTOS, T.M.; SANTOS, P.C.; BACCEGA, B.B.; SCAINI, C. J. Diversidade das plantas brasileiras com potencial anti-helmíntico. VITTALLE-Revista de Ciências da Saúde, v. 28, n. 1, p. 38-49, 2016.

FRANÇA, I. S. X. D.; SOUZA, J. A. D.; BAPTISTA, R. S.; BRITTO, V. R. D. S. Medicina popular: benefícios e malefícios das plantas medicinais. Revista brasileira de enfermagem, v. 61, $\mathrm{n}$. 2, p. 201-208, 2008.

FRANCO, S.E.P.; SOUZA, A.C.R. Resgate do conhecimento sobre as plantas medicinais utilizadas por alunos do programa de ensino de jovens e adultos (EJA) no município de Porto VelhoRO. Revista Saber Científico, p. 1-7, 2016.

IBGE - Instituto Brasileiro de Geografia e Estatística. Censo 2010 - Cidades (Informações sobre os municípios brasileiros). Disponível em: http://cidades.ibge.gov.br/xtras/perfil.php?lang=\&codmun=230190. Acesso em: 03 de fevereiro de 2018.

IPECE. Instituto de Pesquisa e Estratégia Econômica do Ceará. Perfil Básico Municipal Barbalha, 2016. Disponível em: https://www.ipece.ce.gov.br/. Acesso em: 06 de fevereiro de 2019.

ISE - International Society of Ethnobiology (2006). Código de Ética da ISE (com adições em 2008). Disponível em: http://www.ethnobiology.net/ethics.php. Acesso em: 03 de fevereiro de 2020.

MARTIN, G. J. 1995. Ethnobotany: Method manual. World wide fund for nature. London, Chapman and Hall, p. 268.

MONTELES, R.; PINHEIRO, C.U. Plantas medicinais em um quilombo maranhense: uma perspectiva etnobotânica. Revista de biologia e ciências da terra, v. 7, n. 2, p. 38-48, 2007.

OSHAGHI, E.A.; KHODADADI, I.; TAVILANI, H.; GOODARZI, M.T. Aqueous extract of Anethum Graveolens L. has potential antioxidant and antiglycation effects. Iranian journal of medical sciences, v. 41, n. 4, p. 328, 2016.

RAJANI, G. P.; ASHOK, P. In vitro antioxidant and antihyperlipidemic activities of Bauhinia variegata Linn. Indian journal of pharmacology, v. 41, n. 5, p. 227, 2009.

RIBEIRO, D. A.; MACÊDO, D. G.; OLIVEIRA, L. G. S.; SARAIVA, M. E.; OLIVEIRA, S. F.; SOUZA, M. M. A.; MENEZES, I. R. A. Potencial terapêutico e uso de plantas medicinais em uma área de Caatinga no estado do Ceará, nordeste do Brasil. Revista Brasileira de Plantas Medicinais, v. 16, n. 4, p. 912-930, 2014.

RODRIGUES, A. P.; ANDRADE, L. H. C. Levantamento etnobotânico das plantas medicinais utilizadas pela comunidade de Inhamã, Pernambuco, Nordeste do Brasil. Revista Brasileira de Plantas Medicinais, v. 16, n. 3, p. 721-730, 2014.

SÁ, R.D.; SOARES, L.A.L.; RANDAU, K.P. Óleo essencial de Chenopodium ambrosioides L.: estado da arte. Journal of Basic and Applied Pharmaceutical Sciencies, v. 36, n. 2, p. 267-276, 2015.

SANTANA, S. R.; NETO, G. G. Plantas medicinais usadas na medicina tradicional em Dom Aquino, Mato Grosso, Brasil. FLOVET-Boletim do Grupo de Pesquisa da Flora, Vegetação e Etnobotânica, v. 1, n. 9, p. 102-111, 2017.

SHARMA, K. R.; KALAUNI, S. K.; AWALE, S. 2015. Antioxidant, Phytotoxic and Antimicrobial Activities of Methanolic Extract of Bauhinia variegata Barks. Journal of Institute of Science and Technology, v. 20, n. 2, p. 37-41, 2015.

SILVA, G. D.; BOTURA, M. B.; LIMA, H.G.; OLIVEIRA, J.V.A.; MOREIRA, E.L.T.; SANTOS, F. O.; SOUZA, T. S. Evaluation of the anthelmintic activity and toxicity of an aqueous extract of Chenopodium ambrosioides in goats. Brazilian Journal of Veterinary Medicine, v. 38, n. Supl. 1, p. 156-162, 2016.

SILVA, M. D. P.; MARINI, F. S.; MELO, R. S. Survey of cultivated medicinal plants from Solanea, dry area of Paraiba: recognition and recovery of the traditional knowledge. Revista Brasileira de Plantas Medicinais, v. 17, n. 4, p. 881-890, 2015.

SINGH, S.; DAS, S.S.; SINGH, G.; PEROTTI, M.; SCHUFF, C.; CATALAN, C.A.N. Comparative Studies of Chemical Composition, Antioxidant and Antimicrobial Potentials of Essential Oils and Oleoresins Obtained from Seeds and Leaves of Anethum graveolens L. Toxicol Open Access, v. 3, n. 119, p. 2-9, 2017. 
SIQUEIRA, K.M.; BARBOSA, M.A.; BRASIL, V.V.; OLIVEIRA, L.M.C.; ANDRAUS, L.M.S. Crenças populares referentes à saúde: apropriação de saberes sócio-culturais. Texto \& ContextoEnfermagem, v. 15, n. 1, p. 68-73, 2006.

SOUSA, D.A.; OLIVEIRA, A. A.; CONÇEIÇÃO, G. M. Agrobiodiversidade em quintais familiares no município de Caxias, Maranhão. Encilcopédia Biosfera, v. 10, n. 18, p. 3129-3139, 2014.

SOUZA-MOREIRA, T. M.; SALGADO, H.; PIETRO, C.L.R. O Brasil no contexto de controle de qualidade de plantas medicinais. Revista Brasileira de Farmacognosia, v. 20, n. 3, p. 435-440, 2010.

TEIXEIRA, A. S.; MELO, J. I. M. Plantas medicinais utilizadas no município de Jupi, Pernambuco, Brasil. Iheringia. Série Botânica., v. 61, n. 1/2, p. 5-11, 2006.

TRIVELLATOGRASSI, L.; MALHEIROS, A.; MEYRE, C.; BUSS, Z. S.; MONGUILHOTT, E. D.; FRODE, T. S.; SOUZA, M. M. From popular use to pharmacological validation: a study of the anti-inflammatory, anti-nociceptive and healing effects of Chenopodium ambrosioides extract. Journal of Ethnopharmacology, v. 145, n. 1, p. 127-138, 2013.

VÁSQUEZ, S.P.F.; MENDONÇA, M.S.; NODA, S. N. Etnobotânica de plantas medicinais em comunidades ribeirinhas do Município de Manacapuru, Amazonas, Brasil. Acta Amazonica, v. 44, n. 4, p. 457-472, 2014. 